\title{
Mexico's Drug War Is Hindering The Growth Of The Retail Sector Of Texas Border Cities
}

Rutilio Martínez, University of Northern Colorado, USA

\begin{abstract}
Between the first quarter of 2007 and the first quarter of 2012, the retail sales of Texas' border cities grew at an unprecedented low quarterly rate of $0.21 \%$. Mexico's drug war contributed significantly to this low growth by hindering the growth of sales to Mexicans who cross the border to shop. This hindrance is likely to continue as long as Mexico's war on drugs continues to generate high levels of violent crime in the northern part of the country.
\end{abstract}

Keywords: Texas Border Cities; Retail Sales; Sales to Mexicans; Mexican Trade; Exports-of-Manufactures; Drug War

\section{INTRODUCTION}

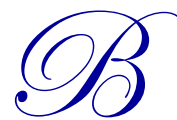

etween the first quarter of 2000 and the first quarter of 2006, the combined retail sales of Brownsville, Edinburg-McAllen, Laredo and El Paso - the border cities of Texas - grew at an average quarterly rate of $0.86 \%$. This relatively high average rate of growth plummeted to an average quarterly rate of $0.21 \%$ between the first quarter of 2007 and the first quarter of 2012 (Federal Reserve Bank of Dallas, 2012). The low quarterly rate of $0.21 \%$ could not be attributed solely to the great recession, for this recession began in December of 2007 and ended in June of 2009. Hence, this low rate of growth must be explained by other factors. One of these is Mexico's drug war.

Mexico's drug war began in December of 2006 at the start of the Calderon administration. Since that date, this war has generated very high levels of violent crime in northern Mexico. This violence has disrupted economic growth and has made traveling in this region of the country unduly dangerous (Cañas, Coronado and Gilmer, 2011, Q III). These effects of the war on drugs have been restraining the growth of sales to Mexican shoppers, the growth of the so called Mexican trade in the border cities of Texas, thereby hindering the growth of retail sales in these cities.

This hindrance has consisted of lost sales. From the first quarter of 2007 to the first quarter of 2012, regression results indicate that these losses were between $\$ 153$ and $\$ 198$ million per quarter, or between 5.2\% and $6.7 \%$ of the quarterly average of $\$ 2,966$ million that these sales had during the above-mentioned period.

President Peña Nieto, whose administration began in December of 2012, has been far less vocal than his predecessor in its opposition to organized crime and has stated his intention to reduce the violence that the drug war has generated. Despite his good intentions, press reports indicate that during the first three months of his administration, there were more than 3,000 homicides related to the war on drugs, which included the killing of 67 law enforcement agents and at least 40 innocent bystanders. These results suggest that Mexico's war on drugs will continue obstructing the growth of retail sales in the border cities of Texas.

The next section discusses factors that explain why Mexican consumers are likely to continue flocking to the border cities of Texas to buy all kinds of goods, despite the fact that Mexico's economy is one of the most open in the world. The subsequent section three discusses regression results that link the retail sales of the Texas border 
cities to Mexico's war on drugs followed by a section analyzing (very briefly) the causes of Mexico's drug war and what the authorities of Texas border cities can do to reduce the negative effects of this war on the retail sales of their cities. The last section contains conclusions.

\section{Motives of the Mexican Consumer To Go Shopping to Texas Border Cities}

The North American Free Trade Agreement (NAFTA) signed by the U.S., Canada and Mexico on December 17, 1992, began its implementation on January of 1994. Since then, Mexico has signed and implemented another 12 free trade agreements. These include treaties with the European Union, the European Free Trade Association, eight Latin American countries, Israel and Japan (Villarreal, 2012). Mexico's economy could, therefore, be considered one of the most open in the world.

This openness allows Mexican stores to import, at low or zero tariffs, practically any goods demanded by Mexican consumers, which implies that Mexicans have no need to go shopping in the border cities of Texas. Yet, according to the Federal Reserve Bank of Dallas, in recent years, the shares of the retail sales of Texas border cities that corresponded to the Mexican trade was $15 \%$ in El Paso, $40 \%$ to $45 \%$ in Laredo, $35 \%$ to $40 \%$ percent in Edinburg -McAllen, and 30\% to 35\% in Brownsville (Coronado and Phillips, 2012). Such high shares indicate the presence of factors in Mexico's retail sector that induce Mexicans to cross the border to shop.

One of these factors is the oligopolistic structure of Mexico's retail sector. This structure allows Mexican chain stores to charge prices for imported goods that are significantly higher than the prices that these goods command in international markets. Also due to this structure, Mexican chain stores offer selections and customer services that are inferior to those offered by U.S. chains operating in Texas border cities.

A second factor is the marginal presence in Mexico of stores that sell used goods. Used goods are cheap, and cheap goods are the type of goods that Mexican consumers of the working and middle classes can afford. In Mexico, however, stores that sell used goods, second-hand stores, are very limited in number and tend to be poorly stocked. In contrast, the Texas border cities have a good number of well stocked second-hand stores that sell clothing, furniture, appliances and other household items at prices that fit the limited budgets of the growing number of working and middle class Mexican consumers (Cañas, Coronado and Phillips, 2006).

Not directly related to Mexico's retail sector, but still a factor that promotes the Mexican trade in Texas border cities, is the status consciousness of upper middle class Mexicans. For most Mexicans of this narrow segment of the growing middle class, foreign trips are de rigueur since successful professionals and businessmen, as well as high ranking bureaucrats, are expected to have some international experience. Most upper middle class Mexicans would, of course, like to fulfill this requirement by going to Europe, Canada or to U.S. cities like New York City or San Francisco. Trips to these places are, however, too expensive for the budgets of the majority of upper middle class Mexicans. Thus, for many members of this growing class, especially for those living in the northern parts of the country, trips to the border cities of Texas not only fulfill this social requirement, but such trips also give them the opportunity to go shopping in the high-end stores of these cities, which tend to be better stocked and offer better prices than the high-end stores of Mexico.

The factors mentioned above have promoted the growth of the Mexican trade in Texas border cities because, during the last two decades, Mexico's economy has grown enough to start forming working and middle classes. This growth has been the result of economic policies that have lowered inflation, increased openness and facilitated the formation of a dynamic export-of-manufactures sector (Alexeenko, 2013; Cañas, Coronado and Gilmer, 2011, QI). So, if the factors mentioned above persist and Mexico's government follows the economic policies it has been following for the last two decades, it is very likely that, despite the war on drugs, the Mexican trade will continue to grow and become even more important for the retail sector of Texas border cities.

\section{The Effect of the Drug War on the Retail Sales of Texas Border Cities}

To determine if the war on drugs has had a statistically measurable effect on the retail sales of the border cities of Texas, the following model is proposed: 
$Y_{t}=\beta_{0}+\beta_{1} X_{1 t}+\beta_{2} X_{2 t}+\beta_{3} X_{3 t}+\beta_{4} X_{4 t}+\varepsilon_{t}$

$Y_{t}$ is the sum, in millions of dollars of retail sales of Brownsville, Edinburg-McAllen, Laredo and El Paso in quarter $t$; where $t=1$ corresponds to quarter one of 1994, and where the last observation, $t=73$, corresponds to the first quarter of 2012. This variable was used as a proxy of the Mexican trade because its value is not known, since neither Mexican customs nor U.S. trade authorities keep track of the value of purchases made by Mexican shoppers in Texas border cities. The values of this variable were found in the Research and Data section of the web page of the Federal Reserve Bank of Dallas.

$X_{1 t}$ is Mexico's quarterly exports-of-manufactures in millions of dollars. The value of these exports was used to represent income in northern Mexico for two reasons; namely, most of the production facilities of the exports-of-manufactures sector are located in northern Mexico and for at least a decade, this sector has led the growth of Mexico's GDP. Lagged observations of this variable were not included because Mexican shoppers tend to use their current income to finance their purchases in Texas (Coronado and Phillips, 2012). The values of this variable were found in the Balanza de Pagos section of the web page of the Banco de Mexico, Mexico's central bank.

Mexico's drug war is represented by $X_{2 t}$. This is a binary variable with a value of one for the quarters which correspond to this war. Since this war started on December of 2006 and is still going, $X_{2 t}$ was entered as one from the first quarter of $2007, \mathrm{t}=53$, to the first quarter of $2012, \mathrm{t}=73$.

$X_{3 t}$ is the quarterly average peso-dollar exchange rate. This variable was included because the peso steadily lost value between 1994 and 2012, which implies that imports became more expensive during these years. Like the data on the exports-of-manufactures, the values of the peso-dollar exchange rate were found in the Balanza de Pagos section web page of Mexico's central bank.

The recession is represented by the binary variable $X_{4 t}$. This variable was assigned a value of one in the quarters when the U.S. economy was in recession. There were two different number of quarters for which $X_{4 t}$ was equal to one because two different lengths of the recession were used. Each of these lengths generated a different estimation of the proposed model. In the first estimation (regression I) the length of the recession was that proposed by the Bureau of Labor Statistics, from December of 2007 to June of 2009. In regression II, the length of the recession used was the one proposed by the business media, from the first quarter of 2008 to the fourth quarter of 2009.

$\varepsilon_{t}$ is the error. As usual, the error was assumed to be normally distributed with a mean equal to zero and standard deviation equal to $\sigma_{\varepsilon}$. The regression's results are summarized in Table 1 .

Table 1: Regression Results

\begin{tabular}{|l|c|c|}
\hline & Model I Recession: & Model II Recession: \\
& I 08 to II 09 & $1,611.36^{*}$ \\
\hline$\hat{\beta}_{0}$ & $1,591.76^{*}$ & $(20.258)$ \\
\hline$\hat{\beta}_{1}$ & $(19.74)$ & $.03^{*}$ \\
& $-0289^{*}$ & $(11.844)$ \\
\hline$\hat{\beta}_{2}$ & $(11.78)$ & $-198.526^{*}$ \\
& $-153.15^{* *}$ & $(-2.826)$ \\
\hline$\hat{\beta}_{3}$ & $(-2.349)$ & $-25,623$ \\
& -17.935 & $(-1.92)$ \\
\hline$\hat{\beta}_{4}$ & $(-1.388)$ & $185.34^{*}$ \\
& $155.938^{* *}$ & $(2.744)$ \\
\hline$R^{2}$ & $(2.252)$ & 0.897 \\
\hline $\mathrm{F}$ & 0.89 & $149.4^{*}$ \\
\hline
\end{tabular}

Numbers in parentheses are t statistics * Significant at one percent level $* *$ Significant at the five percent level 
As can be seen, the estimated coefficient for the exports-of-manufactures variable, $\hat{\beta}_{1}$, is very significant in both regressions. The values of this coefficient suggest that a dollar of Mexico's export-of-manufactures generated approximately three cents of retail sales in Texas border cities. This effect is small on a per dollar basis; however, at the aggregate level, this effect is rather large, for exports-of-manufactures generate no less than one fifth of Mexico's GDP, which is already above $\$ 1.3$ trillion dollars (Banco de Mexico, 2012).

Also significant, but negative, in both regressions, is $\hat{\beta}_{2}$ - the coefficient for the war on drugs. The values of this coefficient suggest that the war on drugs cost the Texas border cities between $\$ 155$ and $\$ 198$ million per quarter in lost sales between the first quarters of 2007 and 2012. These amounts are, respectively, 5.2\% and 6.7\% of the quarterly average of $\$ 2,966$ million that these sales had during this period of time, a small but still relevant amount.

The coefficient of the peso-dollar exchange rate variable, $\hat{\beta}_{3}$, has a negative sign in both regressions. This indicates that, as macroeconomic theory proposes; the value of the peso and the Mexican trade had an inverse relationship. The lack of significance of this coefficient in the two regressions indicates, however, that the steady devaluation of the peso between 1994 and 2012 had practically no effect on the Mexican trade. The failure of the peso devaluation to negatively affect the Mexican trade is explained by the fact that price level in Mexico and the price of the dollar were weakly but directly correlated. That is, the devaluation of the peso had no effect on the Mexican trade because increases in the peso-dollar rate were followed by non-proportional increases in the price level that caused the said devaluations to be sometimes nominal and sometimes real (Banco de Mexico, 2013).

In both regressions, $\hat{\beta}_{4}$ is significant and has an unexpected positive sign. The significance of this coefficient indicates that the retail sales experienced little variability during the recession, while the unexpected positive sign is explained by the evolution of these sales during the said recession. From a macroeconomic perspective, these sales should have declined steadily during the recession, but that did not happen since by the second quarter of 2009, these sales were growing even though the rest of the economy was still in recession. The recession should also have magnified the negative effect that the war on drugs was having on these sales, yet this did not happen either since the retail sales in five of the six recession quarters exceeded the quarterly average $(\$ 2,966$ million) that these sales had form the first quarter of 2007 to the first quarter of 2012.

\section{The War on Drugs Has No End in Sight}

As already mentioned, the Calderon administration began Mexico's war on drugs in December of 2006. At that time, drug trafficking had been taking place in Mexico for at least seven decades and violence among the different cartels was very visible but well below the current levels. Also at that time, criminal gangs of varied sizes and sophistication - connected and not connected to the drug cartels - had been committing extortions, armed robberies and kidnappings for well over two decades. So, by the time the Calderon administration started its war against organized crime, Mexican society had been afflicted by high levels of crime for several decades (The Economist, 2010).

Fully aware of the fact that the regular state and municipal police forces were poorly equipped and too corrupt to fight the drug cartels, the Calderon administration sent the armed forces, army and navy, and the federal police to combat these criminal organizations. As the government concentrated its efforts against the drug cartels, the frequency and violence of the confrontations between the cartels reached unprecedented levels, while other criminal activities grew practically unchecked. Thus, although the war on drugs may have reduced the number of drug cartels, this war also caused more than 70,000 deaths and generated unprecedented levels of fear and insecurity among the population (The Economist, 2012).

The Peña Nieto administration has been less vocal than the Calderon administration in its opposition to organized crime. Yet, during the first 100 days of the Peña Nieto administration, at least 3,000 people were killed in the war on drugs, while drug trafficking, kidnapping, extortion and armed robbery did not show signs of abating. This suggests that the criminal organizations continue to have the financial resources to purchase weapons, bribe government officials, and recruit people to carry out their illicit activities. Thus, the war on drugs is likely to continue obstructing the growth of the retail sales of Texas border cities. 
This hindrance, however, could be reduced and even eliminated. The Mexican criminal organizations buy the most sophisticated and powerful firearms that can be bought in the U.S. - legally and illegally - in Texan and Arizonan cities located on or close to the border. The liberal access to these weapons has equipped Mexico's criminal organizations with firepower that promotes violence and that, within Mexico, can be matched only by the armed forces (Feinstein, Schumer and Whitehouse, 2011). Thus, if the authorities of the cities located close to the border find ways to preclude Mexican citizens from buying firearms, they will reduce, and eventually eliminate, the obstruction that Mexico's war on drugs has had on the growth of retail sales in the border cities of Texas.

\section{CONCLUSIONS}

The macroeconomic policies that Mexico's government have been implementing for the last two decades, and that the Peña Nieto administration is continuing, have not transformed Mexico into a developed nation. Yet, these policies have caused the slow, but persistent, growth of both the size and income of Mexico's working and middle classes. This growth, combined with the remarkable resilience of the oligopolistic structure of Mexico's retail sector, is increasing the potential number of Mexican consumers who have the income and the motive to go shopping in the border cities of Texas. The Mexican trade in the border cities of Texas could, therefore, be said to have good prospects of growth in the foreseeable future.

This optimistic prospect is, however, thwarted by Mexico's war on drugs. The unprecedented levels of violence that this war has generated across northern Mexico will continue to hinder the growth of the Mexican trade and thereby the growth of retail sales in the border cities of Texas. This hindrance has been small and is likely to continue being rather small; yet, it is relevant for the economies of these cities.

Two factors cause this relevancy. The first one is the importance that the retail sector has for the economies of these cities; in all of them, the retail sector is one of the sectors that leads economic growth. The second factor is the relative economic conditions of the cities in the border area - they are the least prosperous of Texas. Hence, any increase in economic activity will be quite welcomed by the population and will help to reduce, in a visible way, the wealth gap between the border cities and other metropolitan areas of Texas (Gilmer and Coronado, 2012).

The authorities of the border cities of Texas do not have the power to influence the crime-fighting policies that Mexico's government decides to implement. However, if they find ways to preclude the sale of firearms to Mexicans in their cities, the authorities of the border cities of Texas would enhance the economies of their cities and would contribute to increasing the economic ties between their cities and a segment of Mexican society that is becoming larger and more prosperous.

\section{AUTHOR INFORMATION}

Rutilio Martinez is an associate professor of statistics and international business at the Monfort College of Business of the University of Northern Colorado. He has written several papers about the economies of Latin America and has taught in Germany, Lithuania and the Czech Republic a class that deals with the economies and managerial cultures of Latin America. E-mail: rutilio.martinez@unco.edu

\section{REFERENCES}

1. Alexeenko, A. (2013). Bordering on a Boom: Mexico Manufacturing Builds a Future. EconSouth, Federal Reserve Bank of Atlanta: First Quarter (pp. 23-26).

2. Banco de Mexico. (2012). Balanza de Pagos. Retrieved November 5, 2012 from http://banxico.org.mx/SieInternet/C

3. Banco de Mexico. (2013). Indice de Precios al Consumidor. Retrieved May 14, 2013 from http://banxico.org.mx/SieInternet

4. $\quad$ Cañas, J., Coronado, R. and Gilmer, R. (2011). Trade Conference Explores U.S.-Mexico 'CommonBonds.' Southwest Economy, Federal Reserve Bank of Dallas: First Quarter (pp. 17-19). 
5. Cañas, J., Coronado, R. and Gilmer, R. (2011). Mexico Rides Global Recovery but Still Faces Hurdles. Southwest Economy, Federal Reserve Bank of Dallas: Third Quarter (p.13).

6. Cañas, J., Coronado, R. and Philips, K. (2006). Border Benefits from Mexican Shoppers. Southwest Economy, Federal Reserve Bank of Dallas: Issue 3, May/June (pp.11-14).

7. Coronado, R. and Phillips, K. (2012). Dollar-Sensitive Mexican Shopper Boost Texas Border Retail Activity. Southwest Economy, Federal Reserve Bank of Dallas: Fourth Quarter (p.15).

8. Federal Reserve Bank of Dallas. (2102). Publications and Multimedia, Research and Data, Texas Retail Sales Estimates by Metro. Retrieved November 5, 2012 from http://www.dallasfed.org/research/econdata/tx-retail/.cfm

9. Feinstein, D., Schumer, C., and Whitehouse, S. (2011). Halting Firearms Trafficking to Mexico. Report to the United States Senate Caucus in International Narcotics Control. Retrieved May 14, 2013 from http://www.feinstein.senategov/public/index.cfm?

10. Gilmer, R., and Coronado, R. (2012) El Paso and Texas Border Cities Close the Gap in Per Capita Income. Crossroads, Federal Reserve Bank of Dallas, El Paso Branch: Issue 2, July (pp.2-6).

11. The Economist (2010). Organised crime in Mexico. The Economist. Retrieved May 14, 2013 from www.economist.com/mode/21564897

12. The Economist (2012). Mexico's drug lords. The Economist. Retrieved May 14, 2013 from www.economist.com/mode/17249102

13. U.S. Bureau of Labor Statistics. (2012). The Recession of 2007-2009. Retrieved April 20, 2013 from http://www.bls.gov/spotlight/2012/recession/pdf/recession-bls.spotlight-pdf

14. Villarreal, A. (2012).Mexico's Free Trade Agreements. Report for Congress, Congressional Research Service, Washington D.C., July 3 (p. 3). 